\title{
FOREIGN DIRECT INVESTMENTS AND REGIONAL ECONOMIC PERFORMANCE IN BULGARIA
}

\author{
D. Ganchev* \\ Faculty of Economics, Technical University of Gabrovo, Bulgaria
}

\begin{abstract}
The paper presents the relationship between foreign investment flows and the economic performance of Bulgaria's economic regions. It is a well-known fact that some imbalances exist in the level of development of the economic regions and the territorial localization of foreign direct investments. This uneven distribution - both in terms of economic development and investment allocation - creates serious prerequisites for economic backwardness, depopulation and deepening of demographic problems in some regions.

The purpose of this paper is to draw some conclusions and make recommendations using the methods of economic and statistical analysis with a view to overcome the negative consequences and initiate a process of creating prerequisites for a balanced development of Bulgaria's regions and a more even placement of foreign capital flows at both regional and sectoral level.
\end{abstract}

Key words: foreign investment flows, economic region, financial crisis, investment attractiveness, investment activity

\section{INTRODUCTION}

Foreign direct investments play an important role in the economy of every country. Their positive impact leads to modernization of different sectors of the national economy and, along with that, it gives a lasting effect on the economic development of the different regions. This conclusion holds true for Bulgaria as well. Investment activity and investment attractiveness are a complex set of interrelated factors that have both sectoral and regional projections. In the last quarter of a century, foreign investment flows are extremely unevenly distributed both in the different sectors of the national economy and in the different statistic regions of the country. The investment actions carried out during the economic transition period are due to a common strategy for attracting foreign investments (1). In recent years, an attempt has been made to build a strategic vision for attracting foreign direct investments both in individual sectors and in the statistic regions of the country. It is necessary to make relevant analyses and draw conclusions about the attraction of foreign direct investments to

\footnotetext{
*Correspondence to: Dobrin Ganchev 5300, Gabrovo, Technical University of Gabrovo, 4 "Hadhi Dimitar" Street, Department of Social and Economic Sciences”, tel. 066827428, mail: dobrin@tugab.bg
}

different sectors and their localization in the country at the end of this relatively long period of time.

\section{EXPOSITION}

Undoubtedly, the energy industry has a leading role among the sectors of the national economy and especially in the industry. The development of the industrial sectors is impossible without the dynamic and efficient development of modern energy industry, thanks to which the complex technological and chemical processes can be carried out, the operation of the production equipment, the systems for management and control of production processes can be ensured. At the beginning of 2001, the largest investment procedure in the industry sector was initiated the project for construction of a new 600 megawatt power plant at the Maritza East 1 TPP for the total value of $\$ 850$ million. The main investor was AES Corporation of USA.

One of the most important sub-branches in the Bulgarian industry is machine-building. It developed in the second half of the 20 century, with the first strong push being given to light machine-building, and in the 80 s of the last century the heavy machine-building became a priority. At that time our country had production capacities far outracing the possibilities. 
Since 1990 the machine industry has undergone significant changes that have led to the closure of dozens of businesses, the loss of market positions, to reduction and in some cases cessation of production. It should be noted that there are separate foreign investments which can be considered as "islands" of foreign entrepreneurial activity. These are ABB - Sweden, Liebherr Switzerland, Sparky and Grimmer - Germany, American Standard - USA. Most of them have acquired ownership through participation in the process of privatization and others, such as Liebherr, American Standard, etc., have become owners through the so-called "greenfield investments". The machinebuilding sub-sector, as well as the other subsectors, experience the impact of a number of internal and external difficulties which have a negative impact on the investment climate.

The deep economic crisis, which covered the national economy, affected also one of the subsectors playing a defining role - the electrical and electronic industry. For the most part, the companies in this area are small and mediumsized. Their production is targeted at corporate customers. Market demand exists both for home electronics and for various communication devices, such as wireless phones, answering machines, faxes, modems. The main priorities in the development of information technologies should be the retention of young specialists in the country, a significant contribution to the creation of gross domestic product through development and production of modern computer and communication systems.

Table 1. Foreign direct investment for the period $1996-2015$ (EUR mln)

\begin{tabular}{|c|c|c|c|c|}
\hline 1996 & 1997 & 1998 & 1999 & 2000 \\
\hline 137.3 & 570.2 & 605.1 & 866.0 & 1103.3 \\
\hline 2001 & 2002 & 2003 & 2004 & 2005 \\
\hline 903.4 & 980.0 & 1850.5 & 2735.9 & 3152.1 \\
\hline 2006 & 2007 & 2008 & 2009 & $\mathbf{2 0 1 0}$ \\
\hline 6221.6 & 9051.8 & 6727.8 & $\mathbf{2 4 3 6 . 9}$ & 1151.2 \\
\hline 2011 & 2012 & 2013 & $\mathbf{2 0 1 4}$ & $\mathbf{2 0 1 5}$ \\
\hline 1330.2 & 1070.3 & 1092.4 & 1339.1 & $\mathbf{1 5 9 3 . 4}$ \\
\hline
\end{tabular}

Source: Bulgarian National Bank

For the period 1996-2005, the total volume of foreign direct investments amounted to EUR12,929 billion (Table 1 and Chart 1). During this period, public assets worth more than BGN 100 billion were privatized. Foreign investment flows for the period under survey were extremely unevenly distributed across the different sub-sectors of the industry. The investment actions carried out during the economic transition period were due to a common strategy for attracting foreign investments.

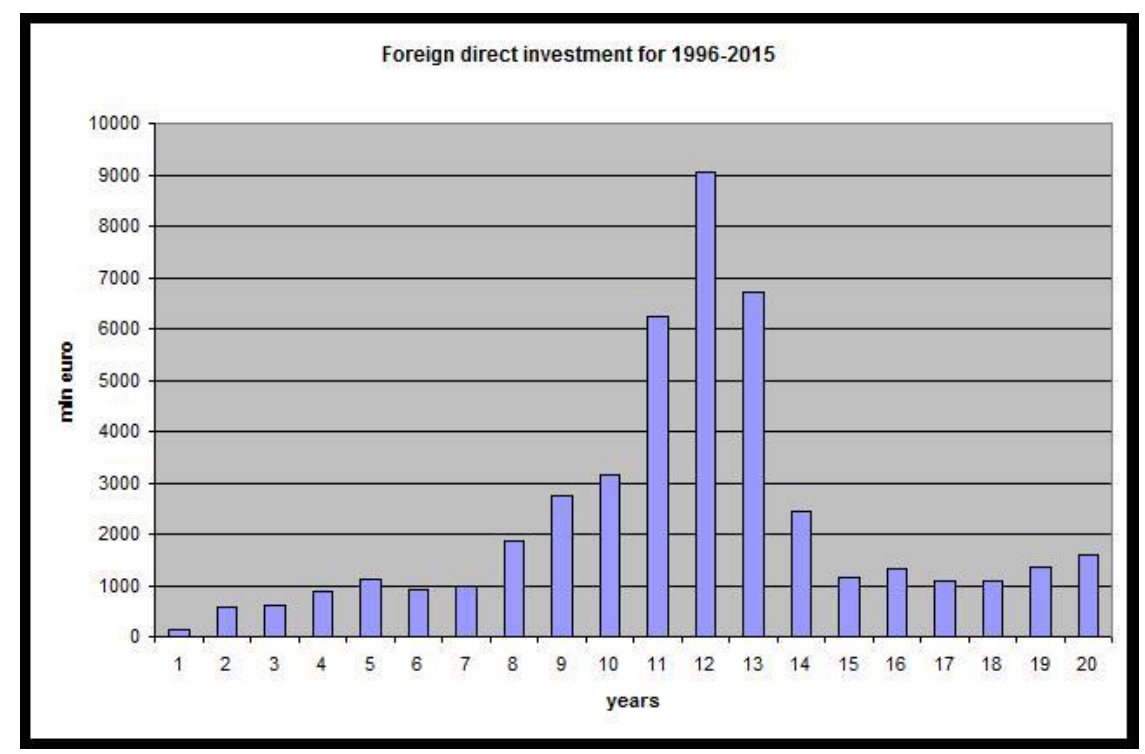

Chart 1. Foreign direct investments in Bulgaria

Foreign direct investments have been one of the main drivers of the world economy over the past few decades, despite the fluctuations observed and the volatility of capital flows during the financial and economic crises. It is worth noting that for this nearly twenty-year 
period - from 1996 to 2015 - the country underwent various phases of the economic cycle. These include the crises of 1996-1997 and 20092010. The first crisis was caused entirely by internal factors. Its external manifestation was the special supervision of a large part of the Bulgarian commercial banks and their actual liquidation. The displacement of the negative effects of this crisis began with the introduction of the currency board system in mid-July 1997. The comprehensive set of measures taken contributed to a gradual exit from the recession and to a gradual increase in GDP growth. This was also aided by the flow of fresh capital resources in the form of foreign direct investment.

The 2008 global crisis began as a financial crisis in September with the bankruptcy of the American investment bank Lehman Brothers and the problems with the largest insurance company AIG. It covered the entire US financial and insurance sector and spread very rapidly all over the world, leading to global banking and insurance problems. Liquidity problems started to grow a lot, passing through the narrow national borders of the individual countries. These events caused a huge increase in the expected risks as the banks faced the solvency of major financial authorities with existing problems. The liquidity demand jumped to new heights and market volatility rose more than ever before. The liquid assets were sold at prices at a situation like a fire, the credit lines to hedge funds and other financial institutions, used as intermediaries in the so-called shadow banking system, were greatly reduced. The most secure type of securities, such as high-yield corporate bonds, sharply reduced the spread, the flow of commercial and working capital was severely disrupted, banks tightened the lending standards and the property prices fell rapidly

The emerging markets, which in the earlier phase of the crisis were relatively protected from distortions, thanks to the limited exposure of the US secondary financial market, were severely hit by these events.

The newly issued securities were brought to a virtual stop, the interbank flows were curtailed, bond spreads rose, stock prices collapsed, and financial markets were under strong pressure. Beyond the overall increase in risk, capital flows were curtailed under the influence of a number of opposite factors, including the damage caused to the banks (especially in Western Europe) and the hedge funds that were the main channels previously, as well as the desire to put the funds "under the umbrella" by increasing the amount of provisions to guarantee the developed markets.

Although the global catastrophe has been prevented with certain urgent efforts, this sharp escalation of financial tensions has damaged the global economy through many channels. The critical situation with credits caused pressure and violation of the technology of securities issuance and harm even to the debtors with high credit rating. The sharp downturn in the real estate market, as well as the ongoing "bursting of the soap bubble" with housing has led to a large loss of household welfare.

The economic crisis has resulted in the rapid deterioration of industrial production, which has led to financial constraints in the broken feedback between the real and the financial sector, undermining the efforts of politicians to find a remedy for the situation. Thus the influence of reality was felt quickly and unambiguously. The industrial production and wholesale trade fell sharply in the fourth quarter of 2008 and continued to decline rapidly in early 2009 in both developed and emerging economies (3). The sale of investment goods and durable goods, such as cars and electronics, done on credit, marked a significant drop, while stocks of commodities began to increase.

The latter crisis has many dimensions in Bulgarian conditions. It should be noted that, in the years before the global crisis, the national economy had a significant growth - in the last three years it fluctuated between 6 and 7\%. Some economic sectors had a real boom. These include construction, real estate, tourism, services, etc. Moreover, the good economic conjuncture was accompanied by record foreign investment flows in the years 2006-2008. For this period, the fiscal reserve exceeded BGN 8 billion, and the foreign exchange reserve was estimated at over BGN 22 billion.

Table 2. GDP at comparable prices for 2010 (BGN mln)

\begin{tabular}{|c|c|c|c|c|}
\hline $\mathbf{1 9 9 6}$ & $\mathbf{1 9 9 7}$ & $\mathbf{1 9 9 8}$ & $\mathbf{1 9 9 9}$ & $\mathbf{2 0 0 0}$ \\
\hline 47299 & 46784 & 48404 & 45671 & 48429 \\
\hline $\mathbf{2 0 0 1}$ & $\mathbf{2 0 0 2}$ & $\mathbf{2 0 0 3}$ & $\mathbf{2 0 0 4}$ & $\mathbf{2 0 0 5}$ \\
\hline 50268 & 52521 & 55334 & 58964 & 62475 \\
\hline $\mathbf{2 0 0 6}$ & $\mathbf{2 0 0 7}$ & $\mathbf{2 0 0 8}$ & $\mathbf{2 0 0 9}$ & $\mathbf{2 0 1 0}$ \\
\hline 66518 & 71112 & 75205 & 71436 & 71904 \\
\hline $\mathbf{2 0 1 1}$ & $\mathbf{2 0 1 2}$ & $\mathbf{2 0 1 3}$ & $\mathbf{2 0 1 4}$ & $\mathbf{2 0 1 5}$ \\
\hline 73329 & 73690 & 74475 & 75745 & 86372 \\
\hline
\end{tabular}

Source: Bulgarian National Bank 
Foreign direct investments for the period 2006-2008 reached extremely high levels, a peak being recorded in 2007 when they amounted to EUR 9.0518 billion. Much of these investments were invested in sectors with relatively low added value, such as real estate, financial intermediation, manufacturing,
GANCHEV D.

construction, trade and repair. Their total value of almost EUR 20 billion for 2006-2008 exceeded all attracted foreign investments since the start of the transition period. Both the improved internal environment and the favourable international conjuncture contributed to this.

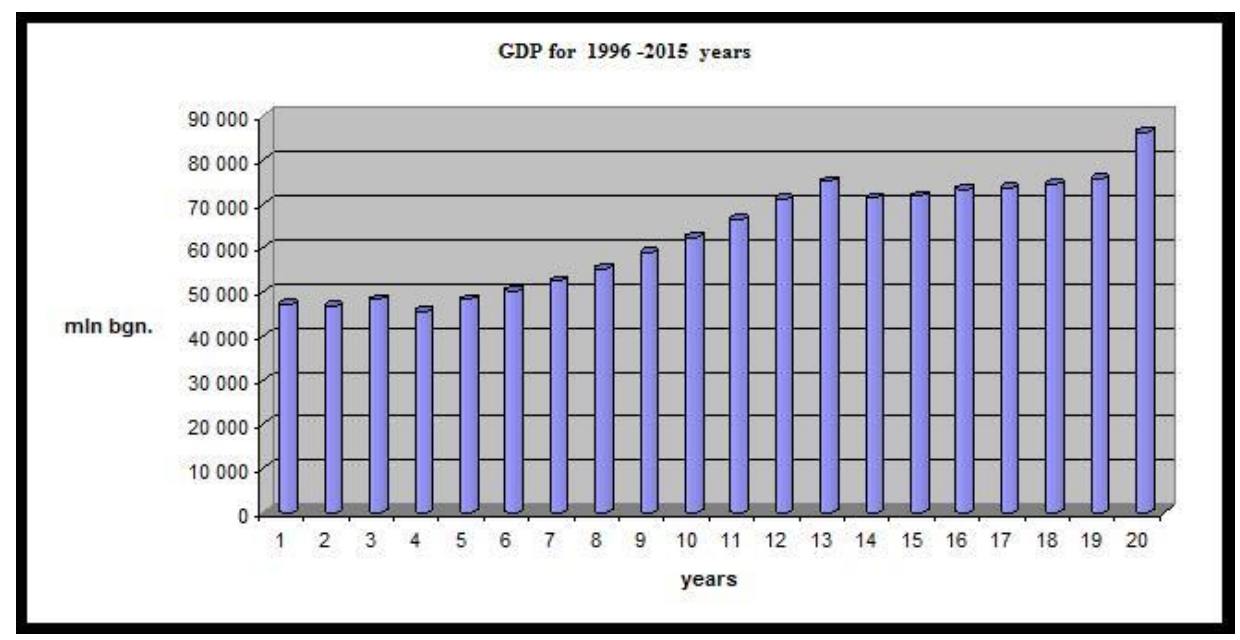

Chart 2. GDP for the period 1996-2015

For this almost twenty-year period, there is a moderate correlation in the years between the gross domestic product and the foreign direct investment (Table 2 and Chart 2). This is evidenced by Spearman's rank correlation coefficient (4):

$$
\rho=1-\frac{6 \sum d^{2}}{n\left(n^{2}-1\right)}
$$

where:

$\mathrm{d}$ - difference between ranks;

$\mathrm{n}$ - number of ranged cases.

The calculation results in the following:

$$
\rho=1-\frac{2112}{5814}=1-0,363=0,637
$$

This result only confirms the theoretical concepts about the relationship and dependence between GDP growth and FDI.

Of particular interest is the analysis of the economic development seen through the prism of foreign direct investments and their localization in the country. If the sectoral analysis gives rise to some concerns, the monitoring of regional development gives far more grounds for negative conclusions.

The problem of regional development and especially economic development is considered to be fundamental in the economic science. It is a subject of research by a number of scientists and is not addressed in this paper (6) . In this regard, it is worth noting that Bulgaria is divided into six statistic regions, which, according to the European standards, represent to a large extent administrative areas. The foundations of this kind of formations were laid down in an older economic and social system.

For the purposes of this paper, parameters have been selected, which are readily available in the statistical databases (8).

The following indicators have been considered and analyzed for each of the six statistic regions:

$>$ Foreign direct investments in non-financial enterprises;

$>$ Produced products;

$>$ Population;

$>$ Expenses for acquisition of tangible fixed assets;

$>$ Expenses for research and development;

$>$ Road network in kilometers;

$>$ Housing. 
On this basis, a model of investment activity and investment attractiveness at regional level has been built by standardizing the indicators.

The formula for determining the investment attractiveness of the statistic regions is as follows [7]:

$$
\mathrm{M}_{\mathrm{i}}=\sum_{s=1}^{c} k_{s} \frac{P_{s i}}{P_{S}}
$$

where:

$\mathrm{M}_{\mathrm{I}}$ - integral indicator of investment attractiveness at regional level comparable to the country average accepted for unit;

$\mathrm{i}=1 . . \mathrm{r},-$ number of statistic regions;

$\mathrm{s}=1-\mathrm{c}$ - proprietary private indices;

$\mathrm{c}$ - quantity of the proprietary private indices;

$\mathrm{k}_{\mathrm{s}}$ - ratio for the relative share (share of the weights) for the s-th index;

$\mathrm{p}_{\mathrm{si}}-$ numeric value for the $\mathrm{s}$-th index for the $\mathrm{i}$ th region;

$\mathrm{p}_{\mathrm{s}}-$ numeric value for the country index;

$\frac{\mathrm{p}_{\mathrm{si}}}{-}$ - standard (normal) numeric value for the

\section{$p_{s}$}

s-th index for the i-th region.

The methodology assumes that all indices have the same weighting factors, which means that $\sum_{s=1}^{c} k_{s}=c$ is equal to one. It should be noted that the number of indices is dynamic and can be changed. For each positive index that measures investment attractiveness at regional level the average standard is equal to one.

The statistical data have been processed by Excel and they are shown in Table 3.

Table 3. Investment attractiveness of the statistic regions

\begin{tabular}{|l|l|}
\hline $\begin{array}{l}\text { Statistic } \\
\text { region }\end{array}$ & $\begin{array}{l}\text { Ratio } \\
\text { Investment } \\
\text { Attractiveness }\end{array}$ \\
\hline South-West & $\mathbf{0 . 3 2 6 2}$ \\
\hline South-East & $\mathbf{0 . 1 6 5 8}$ \\
\hline SouthCentr. & $\mathbf{0 . 1 5 9 9}$ \\
\hline North-East & $\mathbf{0 . 1 4 0 3}$ \\
\hline NorthCentr. & $\mathbf{0 . 1 0 6 9}$ \\
\hline North-West & $\mathbf{0 . 1 0 2 9}$ \\
\hline
\end{tabular}

The results obtained can lead us to several conclusions:

- There is a sharp distinction between Northern and Southern Bulgaria in favour of the latter in terms of investment attractiveness;
- The Southwestern statistic region, in which the country's capital is located, exceeds two to three times the other statistic regions;

- Second and third are the Southwestern and the South Central regions, whose economic potential is significant;

- The stand-alone position of the Northeastern region stands out and tangents (approaches) to the South Central region;

- The last two places occupy the North Central and the Northwestern regions respectively, with more and more the North Central region coming to the last place and the gap more and more melting;

- Investment attractiveness is to a large extent also a litmus for the socio-economic development of the surveyed statistic regions.

To determine the investment activity of foreign investors at regional level, it is necessary to use two private indicators that can be integrated according to the multidimensional average formula, in our case - twodimensional average:

- Total value of attracted foreign investments in the region for a given period;

- Growth rate of foreign investments.

It should be noted that the volume of foreign investments (excluding those in newly-built sites) is determined by the formed and the existing sectoral structure of the economy. In order to measure the investment activity, volumetric and dynamic indices can be used that complement each other and allow through integration to obtain a comprehensive assessment of the state of investment activity of a certain region:

$$
I_{a_{i}}=\left(\left(\frac{I_{1}}{I_{0}}+\frac{T_{1}}{T_{0}}\right)^{*} \frac{1}{2}\right)
$$

where:

$I_{a}-$ integral indicator for performance evaluation:

$\mathrm{I}_{0}$ - volume of foreign investments in the base year;

$I_{1}$ - volume of foreign investments in the current year;

$\mathrm{T}_{0}$ - growth rate of foreign investments during the year preceding the base year;

$\mathrm{T}_{1}$ - growth rate of foreign investments in the base year.

In the formula used, the relative weights of both indicators are assumed to be equal to one. In some cases, however, differentiation of the relative weights of both indicators is needed. In 
GANCHEV D.

order to ensure the integrity and comparability of numerical characteristics of the investment attractiveness and investment activity at regional level, it is necessary to take into account only foreign investment flows by sectors such as industry, trade and other industries or in real assets. On this basis, links and relationships between investment attractiveness and investment activity at regional level can be established.

The data processed by Excel according to the existing and applied methodology show the following rankings (Table 4):

Table 4. Investment activity in the statistic regions

\begin{tabular}{|l|l|}
\hline $\begin{array}{l}\text { Statistic } \\
\text { region }\end{array}$ & $\begin{array}{l}\text { Ratio } \\
\text { Investment } \\
\text { Activity }\end{array}$ \\
\hline South-West & 1.838 \\
\hline SouthCentr. & 1.818 \\
\hline North-East & 1.076 \\
\hline South-East & 0.828 \\
\hline North-West & -1.667 \\
\hline NorthCentr. & -2.885 \\
\hline
\end{tabular}

The analysis of the obtained results shows that two statistic regions - the Southwestern and the South Central show approximately the same results in terms of attracting foreign direct investments in the real sector. The third place is for the Northeastern region with its centre - Varna and the whole Black sea coast that are very attractive for foreign investments. However, there are also negative trends in the dynamics of attracting foreign direct investments in the Northern Central and the Northeastern economic regions, with a tendency for withdrawal of foreign capital flows. This is evidenced by the negative ratio of investment activity.

The investment activity in individual regions, as noted, is measured through the volume of foreign investments attracted and especially investments in the real (non-financial) sector. The ranking by investment activity allows estimating the place of each region by the volume of attracted investments (see Table 4).

The obtained results make it possible to determine the correlation dependence between the phenomenon-sign (investment attractiveness) and the phenomenon-result (investment activity), using the previously used Spearman's rank correlation coefficient.

$$
\rho=1-\frac{6 * 13}{6(6 * 6-1)}=0,6286
$$

The calculated indicator shows a moderately strong correlation between investment attractiveness and investment activity and confirms the theoretical concept about the existence of a relationship between investment activity and investment attractiveness.

Foreign investments are mainly concentrated in the capital, in the largest cities, along the Black Sea coast and in some border regions. They are extremely unevenly distributed. The factors for this picture are many and different. The regional policy of the countries in the European Union is aimed at overcoming the differences in the economic development and an integral part of it is the investment policy. Most of all foreign direct investments for the period are concentrated in the Southwestern region $-62.2 \%$. They also include the capital, which has attracted foreign capital flows of EUR 12111789800 or $53.61 \%$ of all investments in the country. It should be noted that this trend is upward, with the increase compared to the previous year by $3.60 \%$.

On the second place, the Southeastern statistic region has an amount of attracted investment of EUR 2897055700 , which represents 12. $82 \%$ of all foreign investments in real assets in the country. The leader in this area is Bourgas and its area, which is a major industrial center and an attractive place for investment in real assets.

The third place is occupied by the Northeastern statistic region, whose foreign direct investment accounts for $10.06 \%$. Here the indisputable leader is Varna, which, with its EUR 1760956 700, ranks second after Sofia. In Varna region, the industrial zone of Devnya has attracted the largest volume of foreign investment in real assets. The undoubted role here plays the great investment construction of hotels, new industrial sites, etc.

Fourth is the South Central region with $8.3 \%$ of attracted investment and more than $80 \%$ of the investments in the region are concentrated in the Plovdiv region. This area is one of the most dynamically developing in the country. There are over 300 enterprises with foreign and mixed participation, which form powerful cluster formations.

The fifth and the sixth place are occupied by the North Central and Northwestern statistic regions with $3.88 \%$ and $2.75 \%$ of all investments. Here, there are negative outflows of investment flows, especially following the major financial and economic crisis of 2009. 
GANCHEV D.

Table 5. Attracted foreign direct investments in the statistic regions

\begin{tabular}{|l|l|l|}
\hline № & $\begin{array}{l}\text { Statistic } \\
\text { Region }\end{array}$ & $\begin{array}{l}\text { FDI } \\
\text { thousand) }\end{array}$ \\
\hline 1 & South-West & $\mathbf{1 4 0 5 3 1 4 6 . 8 0}$ \\
\hline 2 & South-East & $\mathbf{2 8 9 7 0 5 5 . 6 0}$ \\
\hline 3 & North-East & $\mathbf{2 2 7 1 9 1 3 . 7 0}$ \\
\hline 4 & South Central & $\mathbf{1 8 7 4 1 8 3 . 3 0}$ \\
\hline 5 & North Central & $\mathbf{8 7 6 7 5 8 . 0 0}$ \\
\hline 6 & $\begin{array}{l}\text { North-West } \\
\text { Total: }\end{array}$ & $\begin{array}{l}\mathbf{6 2 0 7 9 4 . 8 0} \\
\mathbf{2 2 5 9 3 8 5 2 . 2 0}\end{array}$ \\
\hline
\end{tabular}

Foreign investments in the non-financial sector over the transition period exceed EUR 22 billion (Table 5). However, they are extremely unevenly distributed across the statistic regions. This problem raises certain imbalances in the economic development not only of the districts, regional and municipal centers, but also of all cities in the country. Despite the developed strategies for economic development of the statistic regions, the lagging of large parts of Northern Bulgaria and the favoritism of some regions of Southern Bulgaria is an objective fact. Regardless of the funds and despite the funds under the Operational Programs, this difference has deepened in the last years and it is acquiring the size of an economic gap.

Sectoral preferences are insufficient to attract significant foreign investors, and for the national capital, industry is not yet an attractive field for a massive capital invasion. I would question the advantages of our country, highlighted by the analysts, such as the low labour cost, provided that the labour productivity in the mixed and foreign firms is approaching the European standards. In this way, national income is exported and the pension-insurance and the healthcare systems in the country are in difficulty. Moreover, in some foreign companies from the tailoring, textiles and construction sectors there are drastic cases of violation of the labour legislation, of basic human rules and norms.

In order to provide the appropriate prerequisites for improving the investment climate at regional and national level in medium- and long-term, it is necessary to take a set of measures in the following more important directions:

- $\quad$ Economic environment:

1. Flexible tax policy consisting in the elimination of low-efficiency taxes, the taxation of certain taxes and their administration to municipalities, including revenues.
2. Simplification of procedures for coordinating the documents related to the stages of implementation of investment projects;

3. Elimination and reduction of low-efficiency taxes, which only hinder the private sector and create additional costs for administering them;

4. Minimizing registration, licensing and permission regimes;

5. Orientation towards the types of industries closely related to the fourth industrial revolution.

- Institutional framework

1. Improving the work of the judiciary by shortening the length of court proceedings;

2. Optimization of administrative structures;

3. Closer coordination with the EU countries on the Common Security Policy (9).

\section{CONCLUSION}

Despite the complex economic environment, there are some favorable prerequisites for attracting foreign direct investments. First of all, these are the possibilities for using funds from the Operational Programs financed by the EU budget. Secondly, it is necessary to make a fuller use of the opportunities offered by the Juncker Plan, whose instruments provide a good prerequisite for optimizing the investment environment. Thirdly, it is imperative to update the regional and sectoral strategies and the respective policies.

\section{REFERENCES}

1. Basics terms using in the school process, Volume first, Publishing house of UNWE, Sofia, ISBN 978-954-644-243-7

2. Factors, determining economical growth, Economical alternatives, Publishing house of UNWE, Sofia, First issue , 2008

3. Key indicators, National statistic institute, 2009 г.

4. Gatev K., General theory of the statistic, Publishing company „LIA”, Sofia, 1995

5. Slavova Z. and Staikov K., Bulgaria in the international classification, ten measure for economical growth, Sofia, 2014, ISBN 978954-8624-42-8

6. Tsonkov N., Developing regions and markets, Publishing house of UNWE, Sofia, 2016, ISBN 978-954-644-896-5

7. Grishina and oth., Complex appraisal of investment activity and investment attractiveness, Journal "Investments in Russia", Fourth issue, 2001

8. http://www.nsi.bg/bg/content/795

9. World investment report - 2016, Investor Natoinality: Policy Challenges United Nation, Geneva, ISBN 978-92-1-112902-1 